\title{
Studies on the Abrasive Wear Behaviour of the Direct Restorative Dental Materials
}

\begin{abstract}
ODETTE LUCA, ANCA VITALARIU*, CATALINA HOLBAN CIOLOCA, MONICA TATARCIUC, DIANA DIACONU POPA
Grigore T. Popa University of Medicine and Pharmacy lasi, Department of Removable Prosthesis, Oral Implantology and Dental Technology, 16 Universitatii Str., 700115, lasi, Romania

Modern coronary restorative materials have a vulnerable aspect, represented by the excessive wear, which determines the severe limitations of applications in the areas of the occlusal contact. In this study, the experimental researches on the abrasive wear behaviour were performed on five direct restorative dental materials belonging to some different classes from the structural point of view: compomer (Compoglass), ceramic (Empress), silver amalgam (Ventura Plus), poly-glass (Artglass), light-cured lining composite resin (Herculite 1). The analysis of the abrasive wear behaviour of direct restorative dental materials imposed their initial characterization from the microstructural point of view and according to the Vickers hardness. Experimental determinations pointed out absolute and relative mass loss, mass intensity and wear speed. The results of the study are useful in choosing a direct resistant and esthetical restoration material.
\end{abstract}

Keywords: restorative material, abrasive wear, micro-hardness

A vulnerable aspect of direct restorative materials, which drastically limits their applications in the occlusal contact areas, is represented by the excessive wear. Direct restorations are represented by fillings or incrustations, which may be indicated by many clinical factors. Patients' desire to have aesthetic restorations in the posterior area of the arch as well as the need to respect the biological principle, of reducing the sacrifice of healthy dental tissue, the degree of coronary destruction, the cariogenic risk existent in the case of some para-functions, are just a few of the elements that should be analysed and that guide us in choosing the coronary reconstruction material [1-4]. In this study, we performed a comparative analysis of the wear behaviour of five dental materials commonly used in the practice of coronary morphology restoring. The conclusions of the research can point outa series of criteria for choosing restorative materials, depending on clinical situation and their performance.

\section{Experimental part}

\section{Materials and methods}

The experimental research on abrasion wear behaviour was performed on five direct restorative dental materials belonging to different classes in terms of structural constitution (Table 1).

The analysis of the abrasive wear behaviour of direct restorative dental materials imposed their initial characterization from the microstructural point of view and according to the Vickers hardness. The experimental attempts were made during the existence of a sliding rotation movement with a continuous character, the surfaces in contact being flat, with a coefficient of coverage being established between: $0<\mathrm{Kac}=0.232<0.5$.
The analysis of the abrasive wear behaviour of direct restorative dental materials imposed their initial characterization from the microstructural point of view and the Vickers hardness.

The microstructural analysis was performed through the optical method in the light field by using a Nephot 2 microscope. An image of the internal architecture of the materials was obtained only for the restorative dental alloy amalgam type, in which case the reflected beam allowed the highlight of the characteristic phases. For the other four dental materials, the microscopic images are difficult to be pointed out because of the transparency of their base matrix.

The micro-hardness of the investigated dental restorative materials was determined by the Vickers method. The experimental trials were performed on a PMT 3 Micro hardness testing equipment (CSI), under the condition of a load force $F=50 \mathrm{gf}$. The values of Vickers hardness for the investigated restorative dental materials were centralized and comparatively analyzed (Table 2).

The wear behaviour of dental restorative materials was studied under conditions specific to a dry friction regime, at the level of the frontal surface of the specimens. The experimental trials were made during the existence of a sliding rotation movement, which is continuous, the surfaces that are in contact being flat, with coefficient of coverage established $0<\mathrm{K}_{a}=0.232<0.5$.

The experimental researches were carried out by using the Capon abrasimeter, for testing the abrasion and the friction resistance. The experimental measurements had the purpose of determining the mass wear, i.e. the absolute variation - $\Delta m$, and the relative variation - Dm of the mass of the specimens, measurements which are found in the

\begin{tabular}{|l|l|l|}
\hline Experimented dental material & Brand & Representative class \\
\hline Compomer & COMPOGLASS & $\begin{array}{l}\text { Hybrid materials (composite resins } \\
\text { modified with poly-acids)-COMPOMERS }\end{array}$ \\
\hline Ceramic & EMPRESS & $\begin{array}{l}\text { Feldspathic ceramic with high content of } \\
\text { leucite }\end{array}$ \\
\hline Amalgam & VENTURA PLUS & Restorative metallic alloys \\
\hline Artglass & Heraeus Kulzer & Poly-glass \\
\hline $\begin{array}{l}\text { Light-cured lining composite } \\
\text { resin }\end{array}$ & HERCULITE & Melted composite diacrylic resins (RDC) \\
\hline
\end{tabular}

Table 1

CATEGORIES OF ANALYZED MATERIALS 


\begin{tabular}{|c|c|c|c|}
\hline Nr. crt. & Dental material & Investigated areas & $\begin{array}{l}\mathrm{MHV}_{50} \text { micro- } \\
\text { hardness }\end{array}$ \\
\hline 1. & Compomer (Compoglass) & Basic matrix & 121 \\
\hline 2. & Ceramic & Basic matrix & 324 \\
\hline \multirow{3}{*}{3.} & \multirow{3}{*}{ Amalgam } & Spherical particles $\mathrm{Ag}-\mathrm{Cu}$ & 302 \\
\hline & & Inter-metallic compound $\mathrm{Ag}_{3} \mathrm{Sn}$ & 265 \\
\hline & & Basic matrix & 92 \\
\hline 4. & Artglass & Basic matrix & 272 \\
\hline 5. & Composite resin & Basic matrix & 163 \\
\hline
\end{tabular}

Table 2

THE VALUES OF VICKERS HARDNESS calculation relations of the two specific wear resistance indicators. They were performed at different time intervals, to which the following lengths of the friction trajectory are corresponding to (Table 3)

\section{Table 3}

THE LENGTH OF THE FRICTION TRAJECTORY

\begin{tabular}{|c|c|c|}
\hline \multirow[b]{2}{*}{$\begin{array}{l}\text { The length of the friction } \\
\text { trajectory } L_{f}[\mathrm{~m}]\end{array}$} & \multicolumn{2}{|r|}{ Trial duration } \\
\hline & $\mathrm{t}[\mathrm{min}]$. & $\mathrm{t}[\mathrm{h}]$ \\
\hline$b^{-}-6-1$ & 0.00 & 0.00000 \\
\hline 500 & 3.22 & 0.05365 \\
\hline 1000 & 6.44 & 0.10730 \\
\hline 1500 & 9.66 & 0.16095 \\
\hline 2000 & 12.88 & 0.21460 \\
\hline 2500 & 16.10 & 0.26825 \\
\hline 3000 & 19.32 & 0.32190 \\
\hline 3500 & 22.54 & 0.37555 \\
\hline 4000 & 25.76 & 0.42920 \\
\hline 4500 & 28.98 & 0.48285 \\
\hline 5000 & 32.20 & 0.53650 \\
\hline 5500 & 35.42 & 0.59015 \\
\hline 6000 & 38.64 & 0.64380 \\
\hline 6500 & 41.86 & 0.69745 \\
\hline 7000 & 45.08 & 0.75110 \\
\hline 7500 & 48.30 & 0.80475 \\
\hline 8000 & 51.52 & 0.85840 \\
\hline
\end{tabular}

The friction torque specific to the dry abrasion wear test was represented by the frontal surfaces of the cylindrical specimens $(\phi 7 \times 50 \mathrm{~mm})$ made of the four investigated dental materials in contact with the frontal surface of a rotating metal disc, covered with a layer of diamond powder. The outer diameter of the disc is of $160 \mathrm{~mm}$ and the contact surface radius is $v=1.25 \mathrm{~m} / \mathrm{min}$. By means of an articulated lever, the necessary force (F2) required to reach contact at the level of the friction surfaces was

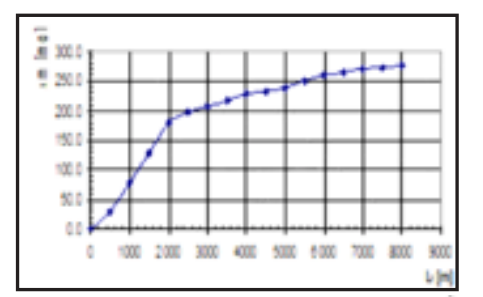

Fig.1. Variation of the absolute mass loss for the compomer applied. The pressure exerted on the specimen and, implicitly, on its contact with the abrasive surface was determined with the relation

$$
p=\frac{F_{2}}{A_{c}}=F_{1} \frac{b}{a} \frac{1}{A_{c}}
$$

where: $A$ is the lever arm corresponding to the force $F_{2}$; a $=25 \mathrm{~mm}$, $B$ is the lever arm corresponding to the force $F$. $; b=50 \mathrm{~mm}, A c$ is contact area (the frontal surface area of the specimen), calculate with the formula:

$$
A_{c}=\frac{\pi d^{2}}{4} \cong 38,5 \mathrm{~mm}^{2}
$$

The loading force (F1) applied on the specimen depends on the mass suspended by the lever arm (b):

$$
F_{1}=m g
$$

Given the action of a mass $m=1 \mathrm{~kg}$, then the loading force $\mathrm{Fl}=10 \mathrm{~N}$ and the amplified force $\mathrm{F} 2=20 \mathrm{~N}$, value which ensures a contact pressure $\mathrm{P}=0.52 \mathrm{MPa}$. The length of the friction trajectory (Lf) was measured using the speed counter.

\section{Results and discussions}

The abrasive wear behaviour of the investigated restorative dental materials was pointed out by determining the mass wear, intensity and speed of mass wear. The mass wear of restorative dental materials. First stage of the experimental trials regarding the abrasion wear behaviour consisted of determining the evolution of the absolute mass losses - $\Delta \mathrm{m}$ and the relative mass losses Äm corresponding to the different values of the friction trajectory length. The experimental results obtained allowed the marking of the variation curves $\Delta m=\Delta m\left(L_{f}\right)$. A first stage consisted in analysing the absolute wear for the compomer and for the ceramic (Fig. 1 and 2), and then we analysed the value of the absolute wear for the other categories of poly-glass materials, silver amalgam and light-cured lining composite resin (Fig. 3).

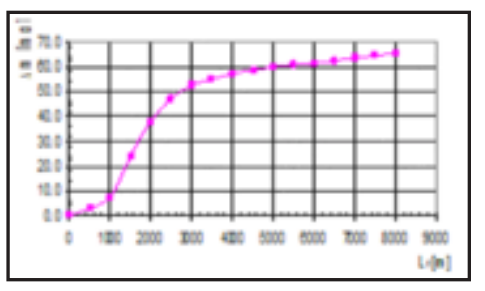

Fig. 2. The variation of the absolute mass for ceramic
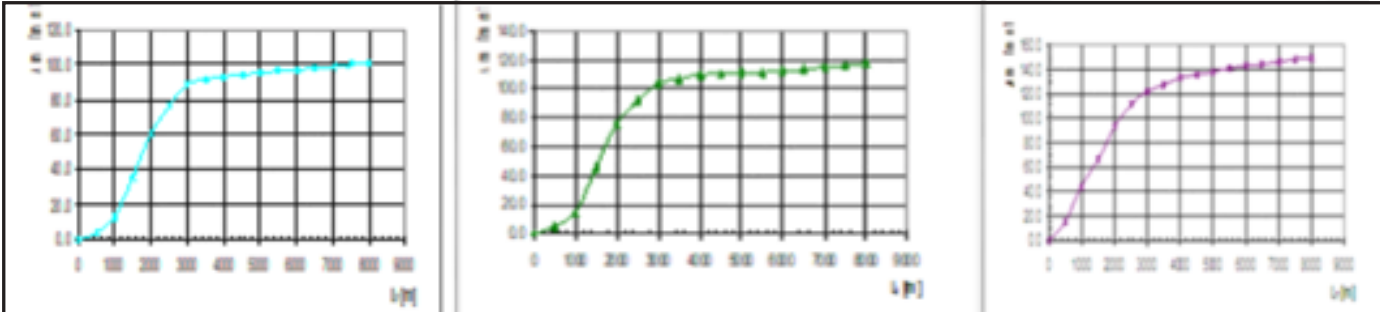

Fig. 3. The variation of the absolute mass loss for poly-glass, silver amalgam and light-cured lining composite resin 


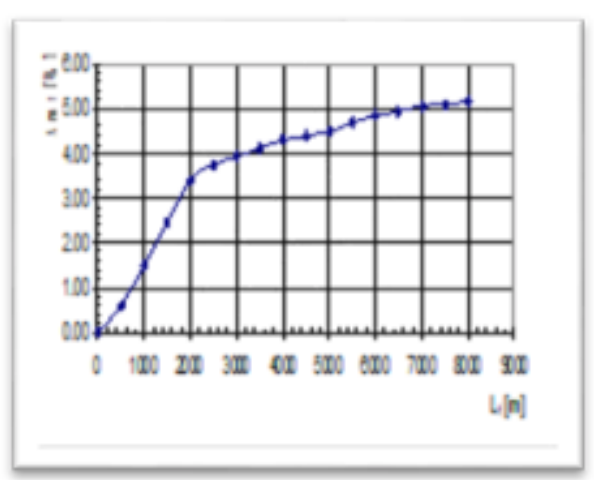

a.

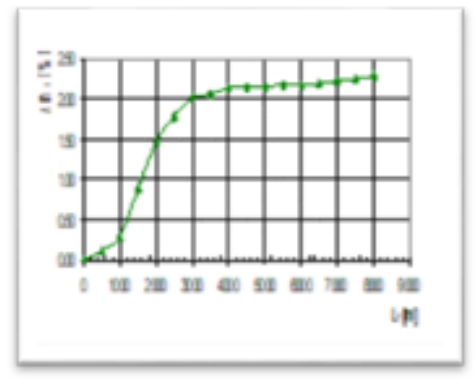

c.

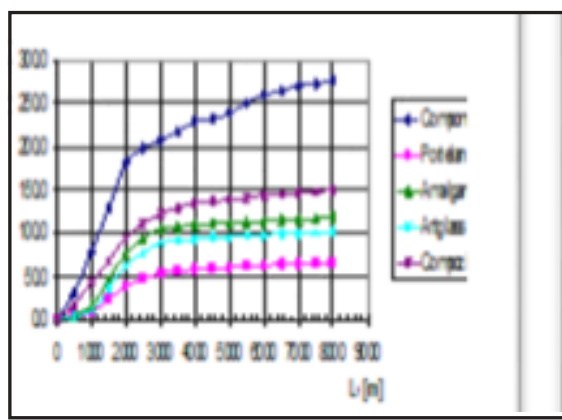

d.

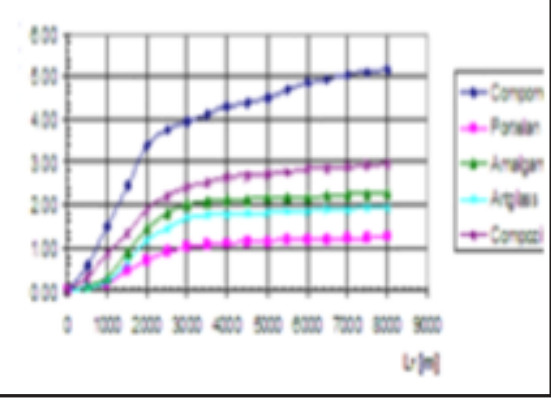

The second indicator of evaluating the abrasive wear behaviour was represented by the mass wear speed, wear for the five restorative materials (Fig. 4).

The experimental determinations highlighted the absolute and relative mass loss, the intensity and the mass wear speed for the five friction torques type: restorative dental material/diamond.

Absolute and relative wear were comparatively analysed, following the diagrams obtained for the analysed material categories (Fig. 5)

The shape of these curves highlights the three stages of the wear process: the initial wear (of lapping), the normal wear (within normal exploitation use) and the final wear (accelerated). The wear resistance of the investigated direct restorative dental materials was evaluated through two specific indicators: the mass wear intensity, $I_{m}$; the mass wear speed, $v_{m}$. The first indicator of evaluating the abrasive wear behaviour was represented by the mass wear intensity, $I_{m}$ (Fig.6).

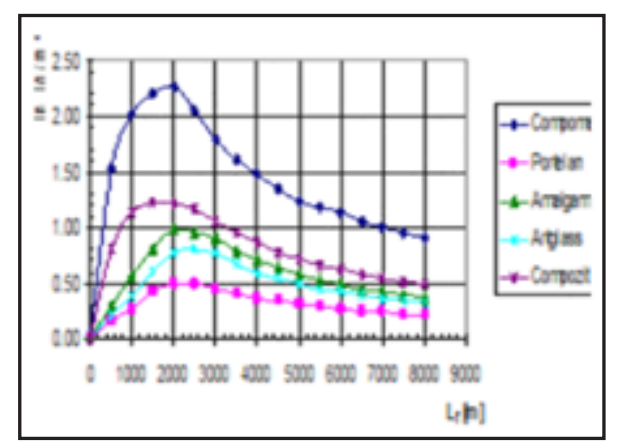

Fig.6. Variation curve Im = Im (Lf) - comparative analysis

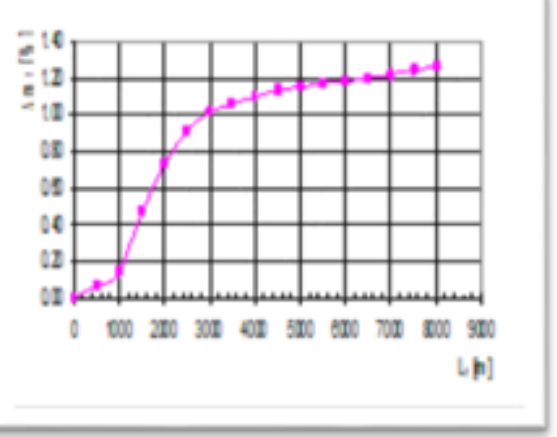

Fig. 4. Variation of relative mass losses for ceramics (a), compomer (b), amalgam

(c), poly-glass (d), composite resin (e) b.

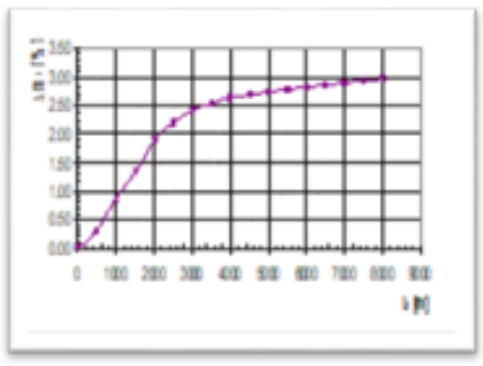

e.

Fig. 5. Absolute and relative mass losscomparative analysis $v_{m}=\frac{\Delta m}{t}[g / h]$, where $t$ is the trial duration, for every $\mathrm{Lf}=500 \mathrm{~m}$ corresponds $\mathrm{t}=3.22 \mathrm{~min} .=0.05365 \mathrm{~h}$.

The experimental research regarding the determination of the abrasive wear behaviour of the five investigated direct restorative dental materials highlighted a series of important practical aspects $[5,6]$. The friction mechanism and wear of the torques can be explained as follows: the friction is due to the roughness of the conjugated surfaces in relative movement, and the wear is a consequence of the reciprocal splintering of the microscopic prominences during the sliding of a rough surface on the other [7-9]. The experimental determinations emphasized the absolute and relative mass loss, the intensity and the mass wear speed for the five friction torques type: restorative dental material/ diamond. The variation curves $\Delta \mathrm{m}=\Delta \mathrm{m}$ (Lf) and $\Delta \mathrm{mr}=$ $\Delta \mathrm{mr}$ (Lf) show the superiority of ceramic-type materials, and poly-glass, low values for compomer and intermediary values for amalgam and composite resin. The values of the angles $\alpha 1$ and á 2 allow the evaluation of the behaviour of each restorative dental material during the initial wear period and the normal exploitation one. The variation mode of the two mass wear indicators, Im and vm, highlights a maximum situated between 1500 and $2500 \mathrm{~m}$, explained by the completion of the splintering process of the microirregularities peaks at the level of the contact surface of each specimen. If for these restorative dental materials 
the micro-hardness characterizes the entire base mass, for the amalgam-type alloy, there are found values specific to the micro-hardness for each identified structural constituent; higher values of large micro-hardness are recorded in poly-glass and dental ceramics [10-14]. The decision to achieve a composite or ceramic inlay in order to restore posterior teeth, taking into account the aesthetic considerations, is based, on the one hand, on an elaborated evaluation of the clinical situation, on the dental tissue resistance and, on the other hand, on economic considerations [15-17]. The mechanical behaviour to the abrasion wear can guide us in choosing the better therapeutic solution, in the sense of using an appropriate, well-known material.

\section{Conclusions}

Choosing an aesthetic material for the coronary reconstruction of the posterior teeth, which presents acceptable features regarding the marginal adaptation and wear resistance, encounters a series of difficulties, although new products constantly appear on the dental market. In this moment, none of the materials existent on the market meets all these requirements. This is why the dentist must choose the optimal solution for restoration depending on the clinical situation. In addition, frequent access and isolation difficulties in the posterior area hinder the correct application of the reconstitution technique, resulting in a non-performant restoration. The realization of inlay-type composite restorations led to the counteraction of some of these inconveniences. In the past few years, composite material manufacturers have brought onto the market various systems that allow the performance of incrustations either by indirect method or by combined direct/indirect techniques. The use of these systems can be justified by many reasons like: the good marginal adaptation and, especially, at the cervical level, the low level of polymerization contraction compared to the composite fillings, the easy material handling outside the oral cavity, the precise occlusal adaptation.

\section{References}

1. TORRES BARROS DUTRA, T., IBIAPINA TAPETY, Z., FERRAZ MENDES, R., MACHADO, J., ROSENDO, R., MOITA NETO, P., Rev. Odontol., 44. No 4, 2015, p. 65.

2. STEFANSKI, S, VAN DIJ KEN, J.W., Clin. Oral Investig., 16, no 1, 2012, p. 147.

3. SARKIS-ONOFRE, R, PEREIRA-CENCI, T., TRICCO, AC., DEMARCO, FF, MOHER, D, CENCI, M.S., J. Esthet. Restor Dent., 31, no 3, 2019, p. 222.

4. DIACONU, D., TATARCIUC, M., VITALARIU, A., STAMATIN, O., FOIA, L., CHECHERITA, L.E., Mat. Plast., 51, no. 3, 2014, p. 271.

5. BALAN, A., STOLERIU, S., ANDRIAN, S., SANDU, A.V., IOVAN, G., SERBAN-PINTILICIUC, V., Rev. Chim. (Bucharest), 66, no. 2, 2015, p. 182.

6. GHIORGHE, C.A., STOLERIU, S., PANCU, G., TOPOLICEANU, C., SANDU, A.V., ANDRIAN, S., Rev. Chim. (Bucharest), 65, no. 9, 2014, p. 1021.

7. AFRASHTEHFAR, K.I., EMAMI, E., AHMADI, M., EILAYYAN, O., ABINADER, S., TAMIMI, F., Prosthet. Dent., 117, 2017, no. 3, p. 345.

8. ANGELETAKI F, GKOGKOS A, PAPAZOGLOU E, KLOUKOS D., J Dent., 53, 2016, p. 12

9. ASTVALDSDOTTIR A, DAGERHAMN J, VAN DIJKEN JW, ET AL., J Dent., 43, 2015, p. 934.

10. DA VEIGA, A.M., CUNHA, A.C., FERREIRA, D.M., J. Dent., 54, 2016, p. 12.

11. RUBEENA ABDUL AZEEM, NIVEDHITHA MALLI SURESHBABU, Journal of Conservative Dentistry, 2018, 21, no 1, p.2

12. MORASCHINI, V., FAI, C.K., ALTO, R.M., DOS SANTOS, G.O., J. Dent., 43, 2015, no. 9, p. 1043.

13. GHIORGHE, C.A., IOVAN, G., CARLESCU, V., ISTRATE, B., PANCU, G., ANDRIAN, S., Rev. Chim. (Bucharest), 68, no. 11, 2017, p. 2623.

14. ALMASI, A., PORUMB, A., PODARIU, A.C., TODOR, L., TOFAN, S.A., POPOVICI, R.A., Rev. Chim. (Bucharest), 68, no. 1, 2017, p. 192.

15. OPDAM, N.J., VAN DE SANDE, F.H., BRONKHORST, E., J. Dent. Res., 93, 2014, no. 10, p. 943.

16. RODRIGUES, S.B., FRANKEN, P., CELESTE, R.K., LEITUNE, V.C.B., COLLARES, F.M., LARSSON, C., WENNERBERG, A., Int. J . Prosthodont., 27, 2014, p. 33.

17. ABDULMAJEED, A.A., DONOVAN, T.E., COOPER, L.F., WALTER, R., SULAIMAN, T.A., J. Prosthet. Dent., 118, 2017, p. 353.

Manuscript received: 21.06 .2019 